\title{
AKTIFITAS FISIK DAN PEKERJAAN TIDAK BERHUBUNGAN DENGAN INDEKS MASSA TUBUH PADA PEREMPUAN USIA 50-60 TAHUN
}

\author{
Abdurahman Berbudi BL \\ Poltekkes Kemenkes Jakarta III \\ email: budiabdulrahman@gmail.com
}

\begin{abstract}
Physical inactivity is an important risk factor for many causes of death, chronic morbidity, and disability. Poor physical activity is also a common world health problem and is a priority of the international health world. Facts are accompanied by clear evidence of an inactivity link to many increased risks of chronic diseases, including heart disease, stroke, and cancer. The purpose of this study was to analyze the relationship between body mass index, physical activity, and occupation in women 50-60 years in Pondok Kelapa Village, Duren Sawit sub-district, East Jakarta. The design of this study is cross-sectional with a total of 130 samples that have been selected by systematic random sampling. The subjects $(n=$ 130) were interviewed using a questionnaire about daily activity in the previous week. Data were analyzed using spss program (Spearman Correlation And Mann Whitney Test). The results of this study indicate that the relationship between physical activity and body mass index is not significant ( $p=0.493 ; p>0.05 ; r=0.61)$. And the relationship between work and Body Mass Index did not have a significant relationship ( $p>0.05)$. Conclusion: physical activity should be measured and for further research not only interviewed using questionnaires.
\end{abstract}

Keywords : Physical Activity, Body Mass Index, Occupation.

\begin{abstract}
ABSTRAK
Inaktifitas fisik merupakan faktor resiko penting pada banyak penyebab kematian, morbiditas kronis, dan kecacatan.Aktifitas fisik yang kurang juga merupakan masalah kesehatan dunia yang umum, dan merupakan sebagai prioritas dunia kesehatan internasional. Fakta disertai bukti yang jelas tentang adanya hubungan inaktifitas terhadap banyak peningkatan resiko penyakit-penyakit kronis, termasuk penyakit jantung, stroke dan juga penyakit kanker. Tujuan dari penelitian ini adalah untuk menganalisis hubungan antara indeks massa tubuh, aktivitas fisik dan pekerjaan pada wanita 50-60 tahun di Kelurahan Pondok Kelapa, Kecamatan Duren Sawit, JakartaTimur. Desain penelitian ini adalah cross sectional dengan total 130 sampel yang telah dipilih secara systematic random sampling. Subyek $(n=130)$ diwawancarai menggunakan kuesioner tentang aktivitas harian pada minggu sebelumnya. Data dianalisis menggunakan Spearman Corelation And Mann Whitney Test. Hasil penelitian ini menunjukkan bahwa hubungan antara aktivitas fisik dan indeks massa tubuh tidak signifikan $(p=0,493 ; p>0,05 ; r=0,61)$. Dan hubungan antara kerja dan Indeks Massa Tubuh tidak memiliki hubungan yang signifikan ( $p>0,05)$. Kesimpulan: aktivitas fisik harus diukur dan untuk penelitian lebih lanjut tidak hanya diwawancara menggunakan kuesioner.
\end{abstract}

Kata Kunci : Aktivitas Fisik, Indeks Massa Tubuh, Pekerjaan 


\section{PENDAHULUAN}

Pada zaman dengan teknologi canggih saat ini, manusia bekerja menjadi lebih hemat waktu, dan tenaga, dan disertai peningkatan taraf hidup. Tetapi dengan perkembangan teknologi mempunyai dampak negative, yang membuat manusia jarang beraktifitas fisik, gaya hidup yang berubah dan kelebihan asupan nutrisi. Perubahan aktifitas fisik ini menyebabkan kurangnya gerak pada anggota gerak tubuh, banyak mengkonsumsi makanan yang berlemak dan siap saji dapat menyebabkan berbagai masalah kesehatan (Lohman et al., 2008).

Kesehatan atau kondisi prima adalah modal yang penting dalam menjalani berbagai aktifitas untuk memenuhi segala kebutuhan dalam persaingan hidup guna memperoleh kehidupan yang lebih baik, Aktifitas-aktifitas itu tentunya akan menguras tenaga, baik fisik ataupun pikiran. Kondisi tubuh yang sehat diharapkan dapat mengatasi rasa lelah yang timbul, karena kelelahan yang dialami dapat menyebabkan menurunnya aktifitas, konsentrasi, berkurangnya kewaspadaan, menimbulkan kegelisahan dan kebingungan, serta dapat memacu timbulnya penyakit dan infeksi, sehingga daya tahan tubuh terhadap penyakit menjadi berkurang. (L. S. R. Preto, Novo and Mendes, 2016).

Sedangkan kurangnya aktifitas fisik merupakan salah satu faktor resiko penyebab penyakit non infeksi utama yang mengakibatkan kematian, penyakit kronis, dan kecacatan di seluruh dunia. Dimana kurangnya aktifitas fisik berhubungan dengan adanya tingkat kematian yang berkaitan dengan penyakit jantung koroner, diabetes mellitus tipe 2 dan penyakit kanker.(Bradbury et al., 2017).

Berdasarkan hasil laporan Riskesdas (Riset Dasar Kesehatan) tahun 2007 diketahui bahwa secara nasional hampir separuh penduduk Indonesia berumur $>10$ Tahun $(48,2 \%)$ kurang melakukan aktifitas fisik. Berdasarkan 33 Provinsi tempat dilakukannya survey nasional ini diketahui 16 provinsi dengan aktifitas fisik yang kurang dimana provinsi DKI Jakarta merupakan salah satu provinsi dengan kurang aktifitas fisik yaitu 54,7\% dengan salah satu daerah kabupaten kurang aktifitas fisik tertinggi adalah Jakarta Timur 56,7\%. Berdasarkan karakteristik responden diketahui kelompok wanita dengan usia 50 tahun keatas $(55,9 \%)$ sesuai dengan hasil survey Riskesdas tahun 2007 diwilayah DKI Jakarta, sedangkan pada wanita usia 65 tahun 
keatas $(58,5 \%)$ sesuai hasil survey nasional Riskesdas tahun 2007. Oleh karena itu dapat disimpulkan bahwa wanita usia 50 sampai 60 tahun merupakan penduduk dengan aktifitas fisik yang rendah khususnya wilayah DKI Jakarta. (Badan Penelitian dan Pengembangan Kesehatan, 2008)

Aktifitas fisik yang dilakukan secara teratur telah diteliti akan menunjukan penurunan gula darah, menormalkan kolesterol darah, menurunkan jumlah lemak visceral, penurunan tanda inflamasi sistemik, meningkatkan fungsi jantung, melancarkan pembuluh darah, dan berperan menurunkan resiko kematian yang disebabkan penyakit kardiovaskular dan diabetes(Rennie et al., 2005). Sedangkan aktifitas fisik yang kurang dapat menyebabkan kadar komposisi tubuh meningkat sehingga dapat terjadi obesitas (Wyszynska et al., 2016).

\section{METODE}

Penelitian yang diambil menggunakan metode cross sectional. Penelitian ini melihat hubungan antara aktifitas fisik terhadap indeks massa tubuh. Teknik sampling yang digunakan adalah Proporsional sampling dengan random sampling adalah salah satu teknik pengambilan sampel yang sering digunakan dalam penelitian.Dari hasil perhitungan didapatkan jumlah sampel sebesar 130 orang subjek penelitian, dimana populasi target penelitian adalah penduduk kota DKI , Kecamatan Duren Sawit Jakarta Timur terdiri dari beberapa kelurahan, berjenis kelamin perempuan berusia 50-60 tahun.

\section{HASIL DAN PEMBAHASAN}

Bedasarkan data statistik demograpi yang dimiliki Kondisi demografis tempat pengambilan sampel yaitu pada RW1 dan RW2. Setelah dilakukan pengamatan pada masing-masing RW secara langsung pada lokasi didapat bahwa RW1 dan RW2 memiliki jarak, akses masuk, dan fasilitas umum yang lebih lengkap dibanding 14 RW lainnya sehingga memudahkan tim peneliti untuk melakukan pengambilan data. Selain pertimbangan tersebut RW1 dan RW2 dipilih menjadi lokasi penelitian karena memiliki jumlah penduduk wanita terbesar. Dari setiap RW diambil 8 RT jadi total keduanya $16 \mathrm{RT}$.

Dari 16 RT yang mengikuti penelitian ini 5 diantaranya tidak memenuhi persyaratan untuk dilakukan penelitian. karakteristik responden berdasarkan, pekerjaan, Indeks Massa Tubuh, dan Nilai aktifitas fisik memiliki jumlah sampel sebesar 130 responden. 
Tabel 1. Karakteristik Subjek Penelitian Di Kelurahan Pondok Kelapa

\begin{tabular}{cccc}
\hline Karakteristik & $\begin{array}{c}\text { Mean } \pm \\
\text { SD }\end{array}$ & $\begin{array}{c}\text { Min- } \\
\text { max }\end{array}$ & $\begin{array}{c}\text { CI } \\
\mathbf{9 5 \%}\end{array}$ \\
\hline $\begin{array}{c}\text { Indek Massa } \\
\text { Tubuh (kg/m²) } \\
(\mathbf{n = 1 3 0 )}\end{array}$ & $25 \pm 4$ & $16-42$ & $24-26$ \\
\hline $\begin{array}{c}\text { Nilai Aktifitas } \\
\text { fisik* } \\
(\mathbf{n = 1 3 0})\end{array}$ & $357 \pm 381$ & $60-2100$ & $\begin{array}{c}291- \\
423\end{array}$
\end{tabular}

*Aktifitas fisik diukur dengan satuan (menit/minggu)

Karakteristik subjek dibagi berdasarkan variabel Nilai Aktifitas Fisik, Pekerjaan, dan Indeks Massa Tubuh. Nilai Indeks Massa Tubuh memiliki nilai minimum sebesar $16 \mathrm{~kg} / \mathrm{m}^{2}$ dan nilai maksimum sebesar $42 \mathrm{~kg} / \mathrm{m}^{2}$. Nilai aktifitas fisik minimum 60 menit/minggu dan nilai aktifitas fisik maksimum 2100 menit/minggu. Berdasarkan tabel 1, nilai rata-rata aktifitas fisik responden adalah 357 yang berarti nilai aktifitas fisik tergolong rendah dari nilai standar deviasi yaitu 381. Nilai confidence interval pada aktifitas fisik berada diantara $291-423$ menit/minggu sehingga dapat disimpulkan untuk nilai aktifitas fisik memiliki range yang cukup besar.

Tabel 2 Frekuensi Pekerjaan Di Kelurahan Pondok Kelapa

\begin{tabular}{|c|c|c|c|}
\hline \multicolumn{2}{|c|}{ Pekerjaan } & $\mathbf{n}$ & $\%$ \\
\hline $\begin{array}{l}\text { Non Ibu } \\
\text { Tangga }\end{array}$ & Rumah & 31 & 23,8 \\
\hline Ibu Rumah & lgga & 99 & 76,2 \\
\hline Total & & 130 & 100 \\
\hline
\end{tabular}

Frekuensi pekerjaan dengan nilai Ibu rumah tangga sebesar 99 orang (76.2\%), Non Ibu rumah tangga sebesar 31 orang $(23.8 \%)$.

Uji Normalitas

Setelah dilakukan analisis deskriptif pada masing-masing variable yang akan diteliti selanjutnya diuji terlebih dahulu normalitas dari variabel aktifitas fisik, IMT dan pekerjaan sebelum dilakukan analisis bivariat lebih lanjut. Hasil uji normalitas tersaji pada tabel 3 di bawah ini. 
Tabel 3 Uji Normalitas Variabel Dependent Dan Independent Dengan Metode Shapiro-Wilk

\begin{tabular}{lcccc}
\hline \multicolumn{1}{c}{ Uji } & \multicolumn{2}{c}{ Shapiro-Wilk } & Uji \\
\cline { 2 - 4 } Normalitas & Statistik & $\mathrm{n}$ & $\mathrm{P}$ & Statistik \\
\hline Indeks & .966 & 130 & $.002 *$ & $\begin{array}{c}\text { Uji } \\
\text { Massa }\end{array}$ \\
Tubuh & & & & Spearman \\
\hline $\begin{array}{l}\text { Aktifitas } \\
\text { Fisik }\end{array}$ & .719 & 130 & $.000 *$ & $\begin{array}{c}\text { Uji } \\
\text { Spearman }\end{array}$ \\
\hline Pekerjaan & .634 & 130 & $.000 *$ & $\begin{array}{c}\text { Uji Mann } \\
\text { Whitney }\end{array}$ \\
\hline
\end{tabular}

*Data tidak berdistribusi normal $(\mathrm{p}<0,05)$

Berdasarkan perhitungan uji normalitas dengan menggunakan metode ShapiroWilk diketahui data variabel, pekerjaan, aktifitas fisik dan indeks massa tubuh, berdistribusi tidak normal sehingga perlu dilakukan uji non-parametrik variabel bersifat Interval yaitu uji Spearmen untuk menguji hubungan masing-masing variabel, aktiftas fisik, indeks massa tubuh, sedangkan pekerjaan dengan menggunakan uji Mann Whitney untuk menguji variable bersifat nominal.
Hubungan Antara Aktifitas Fisik dan Pekerjaan Dengan Indeks Massa Tubuh.

1. Uji hubungan antara variabel Aktifitas fisik dengan IMT.

Uji korelasi masing-masing variabel ditunjukkan pada tabel 5.5. Uji korelasi dilakukan antara variabel aktifitas fisik, dan pekerjaan terhadap variabel Indeks Massa Tubuh (IMT).

\section{Tabel 4. Hubungan Variabel Aktifitas Fisik Dan Indeks Massa Tubuh Di Kelurahan Pondok Kelapa}

\begin{tabular}{|c|c|c|c|}
\hline & \multicolumn{3}{|c|}{ Indeks Massa Tubuh $\left(\mathrm{Kg} / \mathrm{m}^{2}\right)$} \\
\hline & $\begin{array}{l}\text { Aktifitas Fisik } \\
\text { (menit/minggu) }\end{array}$ & $\mathrm{r}=0,61$ & $\mathrm{p}=0,493^{*}$ \\
\hline
\end{tabular}

Berdasarkan uji statistik Spearmen Correlation Coefficient untuk variabel, Aktifitas Fisik, dan Indeks Massa Tubuh didapat bahwa terdapat korelasi aktifitas fisik terhadap Indeks Massa Tubuh $\mathrm{r}=$ 0,61 dengan $\mathrm{P}>0.05$

Dari hasil uji statistik Spearmen dapat disimpulkan tidak ada hubungan yang bermakna antara aktifitas fisik dengan 
Indeks Massa Tubuh (IMT) dan ada signifikan antara Aktifitas fisik dengan corelasi yang tinggi namun tidak Indeks Massa Tubuh.

2. Uji hubungan antara variabel pekerjaan dengan indeks massa tubuh

Tabel 5. Uji Non Parametric Mann Whitney Pekerjaan Dengan IMT Di Kelurahan Pondok Kelapa

\begin{tabular}{|c|c|c|}
\hline \multicolumn{3}{|c|}{$\begin{array}{l}\text { Indeks Massa } \\
\text { Tubuh }\left(\mathrm{Kg} / \mathrm{m}^{2}\right)\end{array}$} \\
\hline Pekerjaan & $\mathrm{Z}$ value $=-0,471$ & $\begin{array}{c}P= \\
0,636^{*}\end{array}$ \\
\hline
\end{tabular}

Dari hasil analisis statistic diatas diketahui hubungan antara pekerjaan denganIndeks Massa Tubuh dengan P > 0,05. Maka tidak ada perbedaan yang bermakna dan null hipotesa diterima.

Untuk melihat distribusi kedua data tersebut maka dilihat distribusi data pada variabel aktifitas fisik dan Indeks Massa
Tubuh. IMT (Indeks Massa Tubuh) dibagi menjadi 3 kategori berdasarkan Marjaana Lahti-Koski tahun 2001 yaitu kurus, normal, gemuk. Sedangkan berdasarkan Riskesdas tahun 2007 aktifitas fisik dibagi menjadi 3 berdasarkan akumulasi waktu per minggu yaitu kategori ringan, sedang, dan berat yang ditunjukkan pada tabel 6 dan tabel 7

\section{Tabel 6. Distribusi Subjek Menurut Kelompok Indeks Massa Tubuh Di Kelurahan Pondok Kelapa.}

\begin{tabular}{lcc}
\hline Karakterisitik & $\mathrm{N}$ & $\%$ \\
\cline { 1 - 1 } Indeks Massa Tubuh & & 1,5 \\
\hline Kurus & 2 & 55,4 \\
\hline Normal & 72 & 43,1 \\
\hline Obesitas & 56 & 100 \\
\hline Total & 130 & \\
\hline
\end{tabular}

Tabel 7. Distribusi Subjek Menurut Kelompok Aktifitas Fisik Di Kelurahan Pondok Kelapa Tahun 2010

\begin{tabular}{lcc}
\hline Karakterisitik & $\mathrm{N}$ & $\%$ \\
\cline { 1 - 1 } Aktifitas fisik & & \\
\hline Ringan & 5 & 3,8 \\
\hline Sedang & 36 & 27,7 \\
\hline Berat & 89 & 68,5 \\
\hline Total & 130 & 100 \\
\hline
\end{tabular}


Berdasarkan tabel 6 diketahui bahwa subjek penelitian memiliki Indek Massa Tubuh normal yaitu 72 orang, lebih besar dibanding subjek penelitian dengan kategori gemuk yaitu 56 orang. Sedangkan pada tabel 7 diketahui bahwa sebagian besar penduduk memiliki aktifitas fisik berat (>150 menit/minggu) sebanyak 89 responden sehingga dapat dikatakan bahwa penduduk Kelurahan Pondok Kelapa tergolong sangat aktif.

Dari hasil penelitian yang dilakukan di Kelurahan Pondok Kelapa, Kecamatan Duren Sawit Jakarta Timur tahun 2010 ini, dapat dilihat bahwa 130 responden yang terpilih sesuai kriteria inklusi yang diantara kriteria tersebut yaitu populasi perempuan yang berusia 50-60 tahun berjumlah sekitar 2949 jiwa. Hal tersebut menunjukkan bahwa populasi perempuan usia 50-60 tahun di Kelurahan Pondok Kelapa cukup besar.

Pengukuran Indeks Massa Tubuh yang dilakukan di kelurahan pondok kelapa pada perempuan usia 50-60 tahun menunjukkan bahwa Indeks Massa Tubuh memiliki nilai normal 24 atau secara umum memiliki proporsi normal. Dimana berdasarkan (Moselakgomo, Monyeki and Toriola, 2015) menyatakan bahwa batas normal Indeks Massa Tubuh yaitu 18 sampai $25 \mathrm{~kg} / \mathrm{m}^{2}$ sedangkan kategori kurus yaitu dibawah $18 \mathrm{~kg} / \mathrm{m}^{2}$ dan kategori kegemukan diatas $25 \mathrm{~kg} / \mathrm{m}^{2}$.
Hasil pengukuran tersebut menunjukkan nilai Indeks Massa Tubuh penduduk perempuan berusia 50-60 tahun di kelurahan Pondok Kelapa sangat baik, nilai normal indeks massa tubuh menunjukkan pada normalnya kriteria berat badan penduduk dengan kriteria berat badan berlebih (overweight) dan kegemukan (obesitas) sangat rendah. Dimana kondisi tersebut merupakan faktor resiko terhadap masalah-masalah kesehatan seperti diabetes, penyakit jantung, tekanan darah tinggi dan masalah kesehatan dan lainnya(Okeyo, Ayado and Mbagaya, 2009).

Berdasarkan studi kepustakaan lebih lanjut ditemukan bahwa aktifitas fisik berhubungan terhadap faktor-faktor seperti kondisi metabolik, nilai berat badan yaitu indeks massa tubuh dan gangguan metabolisme (Didarloo et al., 2011). Dimana kondisi metabolisme meliputi tingkat metabolisme energi, kolesterol darah (LDL, HDL dan trigliserida), persentase lemak tubuh dan gula darah. Aktifitas fisik diketahui merupakan salah satu upaya untuk mengatasi kelebihan lemak sekaligus untuk mencapai tingkat kesegaran jasmani yang baik serta dapat meningkatkan kemampuan fungsional tubuh (Naus, 2015). Selain itu aktifitas fisik juga mempengaruhi komposisi dan tingginya persentase lemak tubuh (A.R Amani, 2010). 
Kegiatan aktifitas fisik menurut Riskesdas tahun 2007 dikategorikan cukup apabila kegiatan dilakukan terus-menerus sekurangnya 10 menit dalam satu kegiatan tanpa henti dan secara kumulatif 150 menit selama lima hari dalam satu minggu. Berdasarkan gambaran hasil analisis statistik menunjukkan rata-rata penduduk berusia 50-60 tahun di kelurahan Pondok Kelapa memiliki aktifitas fisik yang cukup yaitu diatas 150 menit menurut standar Riskesdas tahun 2007.

Penyebab terjadinya overweight dan obesitas mempunyai banyak faktor yang mempengaruhi. Saat ini pola makan merupakan faktor yang paling mempengaruhi terjadinya kasus obesitas, selain itu pola hidup modern ternyata sangat berpotensi menyebabkan obesitas dan overweight. Disamping faktor-faktor tersebut, faktor lingkungan juga sangat berpengaruh, faktor lingkungan yang dimaksud adalah kebiasaan makan dan aktifitas fisik seseorang (Moselakgomo, Monyeki and Toriola, 2015). Tingkat aktifitas fisik sangat dipengaruhi oleh perkembangan teknologi, dimana kemajuan teknologi telah mempengaruhi penurunan tingkat aktifitas fisik (Bradbury et al., 2017).Sehingga dapat disimpulkan bahwa tingkat aktifitas fisik yang tinggi mempengaruhi persentase lemak tubuh, tetapi tidak mempunyai hubungan yang terlalu besar.
Analisis hubungan antara aktifitas fisik terhadap Indeks Massa Tubuh menunjukkan tidak adanya korelasi positif yang ditunjukkan dengan nilai $\mathrm{P}>0,05$ dan tingkat korelasi negatif yang kecil yaitu $r=-0,61$ data ini menunjukkan tingkat korelasi yang terjadi merupakan suatu kebetulan. Sehingga dapat disimpulkan tidak adanya hubungan yang signifikan antara variabel aktifitas fisik terhadap Indeks massa tubuh pada perempuan usia 50-60 tahun. Hasil ini berbeda dengan penelitian yang dilakukan oleh (L. Preto, Novo and Mendes, 2016)yang menemukan bahwa aktifitas fisik dengan Indeks Massa Tubuh memilki hasil signifikan dengan $\mathrm{p}<0.05$ dan $\mathrm{r}=$ 0.096 pada perempuan berusia produktif dengan korelasi kecil pada wanita usia produktif.

Hal ini diperkuat pada studi review yang dilakukan oleh (Gába et al., 2009) yang menunjukkan asosiasi antara nilai estimasi resiko untuk obesitas terhadap tingkat aktifitas fisik pada perempuan usia 56-73 tahun dalam hasil penelitiannya bahwa aktifitas fisik bermanfaat mencegah dan menghambat pembentukan obsitas yang mana hal ini berhubungan erat dengan menurunnya IMT. Dimana dengan aktifitas fisik yang tinggi setelah glukosa habis digunakan untuk energi maka selanjutnya cadangan lemak yang dipakai untuk meproduksi energy, oleh karena itu 
proses terjadinya obesitas akan terhambat, dan peningkatan Indeks massa tubuh menurun.

Sedangkan hasil analisa hubungan antara pekerjaan terhadap Indeks Massa Tubuh tidak menunjukkan adanya hubungan yang signifikan yang ditunjukkan dengan nilai $\mathrm{p}$ $>$ 0,05. Dapat disimpulkan bahwa pekerjaan pada wanita usia 50-60 tahun tidak memiliki hubungan yang signifikan terhadap tingginya Indeks Massa tubuh. Hasil ini berbeda dengan penelitian yang dilakukan oleh(Savegnago et al., 2014). bahwa pekerjaan dengan Indeks Massa Tubuh memilkiki hubungan yang signifikan dengan $p<0,01$. Karena daya tahan tubuh mereka sudah menurun, fungsi kardiorespirasi menurun sehingga mempengaruhi dalam proses bekerja hal ini sesuai dengan pernyataan (Salonen et al., 2015), dan kemungkinan karena pekerjaan hanya dikelompokkan sebagai ibu rumah tangga dan non ibu rumah tangga tidak terlihat jelas perbedaan aktivitasnya sehingga hasil dengan IMT berbeda.

Dari hasil analisis secara keseluruhan dapat disimpulkan bahwa tidak adanya hubungan yang signifikan antara tingkat aktifitas fisik, dan pekerjaan terhadap Indeks massa tubuh pada perempuan usia 50-60 tahun di Kelurahan Pondok Kelapa, Kecamatan Duren Sawit Jakarta Timur.
Kurangnya aktifitas fisik dapat memacu timbulnya peningkatan Indeks Massa Tubuh. Beberapa studi memasukkan faktor usia, sosiodemografi, faktor lingkungan (aktifitas dan konsumsi pola makan) jenis kelamin dan dapatan oksigen maksimal (VO2max) merupakan pengaruh yang penting dalam studi korelasinya. Beberapa penyebab tersebut dapat memberikan asumsi bahwa aktifitas fisik bukan merupakan satu-satunya faktor yang dominan dalam mempengaruhi tingkat Indeks massa tubuh, melainkan saling terkait dengan faktor-faktor lainnya (Park et al., 2014).

Sementara hasil yang didapat dalam penelitian ini menunjukkan bahwa aktifitas fisik, dan pekerjaan tidak mempengaruhi tingginya Indeks massa tubuh seseorang, dimana beberapa faktor yang mempengaruhi tingginya indeks massa tubuh selain aktifitas fisik adalah kondisi mental, perilaku merokok, konsumsi alkohol, pola makan dan gaya hidup (NeilSztramko et al., 2016). Faktor obesitas ini tidak dapat dicegah tanpa memperhatikan pola makan yang teratur yang mempengaruhi metabolisme seseorang (Strauß et al., 2016). Tidak adanya hubungan antara aktifitas fisik dan IMT karena kelemahan pada mengukur aktifitas fisik berdasarkan Interview atau wawancara sehingga kurang akurat. 


\section{SIMPULAN}

Secara umum dari studi korelasi ini dengan metode cross sectional yang dilakukan dengan mengambil variabel dependent dan independent pada saat yang bersamaan memberikan informasi:

1. Pengambilan IMT pada sub sampel yang berjumlah 130 orang menunjukkan penduduk berumur 50-60 tahun di Kelurahan Pondok Kelapa memiliki rata-rata nilai IMT $25 \mathrm{~kg} / \mathrm{m}^{2}$.

2. Nilai aktifitas fisik di Kelurahan Pondok Kelapa memiliki rata-rata 334 menit/minggu yang berdasarkan Riskesdas berkategori aktifitas fisik tinggi, rata-rata persentase pekerjaan berdasarkan 2 kelompok non ibu rumah tangga $n=31(23,8 \%)$, dan ibu rumah tangga $\mathrm{n}=99(76,2 \%)$.

3. Hubungan tidak signifikan terjadi antara aktifitas fisik terhadap indeks massa $\operatorname{tubuh}(\mathrm{P}=0,493 ; \mathrm{p}>0,05)$ dan tingkat korelasi sedang $\mathrm{r}=0,61$.

4. Hubungan tidak signifikan terjadi antara pekerjaan dengan Indeks Massa Tubuh $(\mathrm{P}=0.636 \mathrm{p}>0.05)$.

\section{DAFTAR RUJUKAN}

Badan Penelitian dan Pengembangan Kesehatan (2008) 'Riset Kesehatan Dasar (RISKESDAS) 2007', Laporan Nasional 2007, pp. 1384. doi: 1 Desember 2013.

Bradbury, K. E. et al. (2017) 'Association between physical activity and body fat percentage, with adjustment for BMI: a large cross-sectional analysis of UK Biobank', BMJ Open, 7(3), p. e011843. doi: 10.1136/bmjopen-2016-011843.

Didarloo, A. et al. (2011) 'Factors Influencing Physical Activity Behavior among Iranian Women with Type 2 Diabetes Using the Extended Theory of Reasoned Action', Diabetes \& Metabolism Journal, 35(5), p. 513. doi: 10.4093/dmj.2011.35.5.513.

Gába, A. et al. (2009) 'the Evaluation of Body Composition in Relation To Physical Activity in 56-73 Year Old Women: a Pilot Study. / Hodnocení Tělesného Složení Ve Vztahu K Pohybové Aktivitě U Žen Ve Věku 56-73 Let: Pilotní Studie.', Acta Universitatis Palackianae Olomucensis. Gymnica. Acta Gymnica, 39(3), pp. 21-30. Available at: http://search.ebscohost.com/login.a spx?direct $=$ true $\& \mathrm{db}=\mathrm{sph} \& \mathrm{AN}=482$ $77793 \&$ site $=$ ehost - live.

Lohman, T. G. et al. (2008) 'NIH Public Access', Medicine \& Science in Sports \& Exercise, 40(6), pp. 1163-1170. doi: 10.1249/MSS.0b013e318165c86b. Relationships.

Moselakgomo, V. K., Monyeki, M. A. and Toriola, A. L. (2015) 'Relationship between physical activity and risk factors of body weight disorders among south African primary school children', Biomedical Research-India, 26(4), pp. 730738.

Naus, J. (2015) 'The Relationship Between Physical Activity and Body Composition In Individuals With Type-1 Diabetes'. 
Neil-Sztramko, S. E. et al. (2016) 'Physical Activity, Physical Fitness, and Body Composition of Canadian Shift Workers', Journal of Occupational and Environmental Medicine, 58(1), pp. 94-100. doi: 10.1097/JOM.0000000000000574.

Okeyo, O. D., Ayado, O. L. O. and Mbagaya, G. M. (2009) 'Physical activity and dietary fat as determinants of body mass index in a cross-sectional corelational design.', East African journal of public health, 6(1), pp. 32-36. doi: 10.4314/eajph.v6i1.45740.

Park, J. et al. (2014) 'The relationship of body composition to daily physical activity in free-living Japanese adult men', British Journal of Nutrition, 111(1), pp. 182-188. doi: 10.1017/S0007114513001918.

Preto, L., Novo, A. and Mendes, M. (2016) 'Relationship between physical activity, muscle strength and body composition in a sample of nursing students', Revista de Enfermagem Referência, (December), pp. 81-89. doi: 10.12707/riv16028.

Preto, L. S. R., Novo, A. F. M. P. and Mendes, M. E. R. (2016) 'Relação entre atividade física, força muscular e composição corporal numa amostra de estudantes de enfermagem ', Revista de Enfermagem Referência, serIV(December), pp. 81-89. doi: 10.12707/riv16028.
Rennie, K. L. et al. (2005) 'Association of physical activity with bodycomposition indexes in children aged 6-8 years at varied risk of obesity.', American journal of clinical nutrition, (July), pp. 1320. doi: 10.1093/ajcn.82.1.13.

Salonen, M. K. et al. (2015) 'Physical activity, body composition and metabolic syndrome in young adults', PLoS ONE, 10(5), pp. 112. doi: 10.1371/journal.pone.0126737.

Savegnago, M. et al. (2014) 'Relationship between body composition and level of physical activity among university students', Revista chilena de nutrición, 41(1), pp. 4653. doi: 10.4067/S071775182014000100006.

Strauß, M. et al. (2016) 'Occupation and metabolic syndrome: Is there correlation? A cross sectional study in different work activity occupations of German firefighters and office workers', Diabetology and Metabolic Syndrome. BioMed Central, 8(1), pp. 1-8. doi: 10.1186/s13098-016-0174-0.

Wyszynska, J. et al. (2016) 'Analysis of Relationship between the Body Mass Composition and Physical Activity with Body Posture in Children', BioMed Research International, 2016(1851670), pp. $1-10$. 